\title{
A Comparative Assessment on Soil Environment Quality Based on Chemical Analyses of Heavy Metals
}

\author{
Ning Liu ${ }^{1,2}$, Feng Tian², Li Yang ${ }^{3}$, Wenqian Li², Haiyan Fan', Jin Xia* \\ 'Department of Environmental Science, Jinling College, Nanjing University, Nanjing 210089, China \\ ${ }^{2}$ State Key Laboratory of Pollution Control and Resource Reuse, School of the Environment, \\ Nanjing University, Nanjing 210023, China \\ ${ }^{3}$ School of Geography and Biological Information, Nanjing University of Posts and Telecommunication, \\ Nanjing 210003, China
}

Received: April 6, 2015

Accepted: June 21, 2015

\begin{abstract}
This study investigated the concentrations of 11 metals in soils sampled in 1994 and 2014 from 17 cities throughout Anhui Province in China. Among the tested metals, Mn had the highest concentration and $\mathrm{Hg}$ the lowest. In the past 20 years, soil $\mathrm{Cd}, \mathrm{Co}, \mathrm{Mn}$, and $\mathrm{Cu}$ concentrations demonstrated an increasing trend. In 1994, only Tongling City had a total metal concentration over $1,000 \mathrm{mg} / \mathrm{kg}$, but in 2014, the seriously polluted cities also included Bengbu, Chizhou, Fuyang, Huannai, Huangshan, and Maanshan. Four assessment methods (two pollution indexes and two fuzzy mathematical models) were employed to investigate the soil environment quality of 17 cities. Environmental quality was determined to be Class I (excellent) or Class II (good) for each soil with single-factor index method, and most was identified as Class I for soils with the comprehensive index model. Different from the single-factor index method, the comprehensive index model concerned both the predominant index and average contribution of all pollution indices to integrated environmental quality. Using each of the two fuzzy mathematical methods (single-factor deciding and weighted average models), the environmental risks were determined to be Class I. However, divergence of the membership degree to each pollution class still occurred between the two methods. For fuzzy mathematical methods, membership functions were used to describe the limits between different pollution degrees, and different weights were allocated for the factors according to pollution contribution. Introduction of membership degree and weight of each factor to fuzzy mathematical models made the methods more reasonable in the field of environmental risk assessment.
\end{abstract}

Keywords: environmental assessment, fuzzy mathematical model, heavy metal pollution, pollution index method, soil contamination

\section{Introduction}

Anhui Province is located in eastern China across the basins of the Yangtze River and the Huan River. Anhui is

*e-mail: ebzxx0408@163.com one of the main agricultural regions in China, since the northern part of the province is part of the North China Plain, while the north-central areas are part of the Huan River watershed. Both of these regions are characterized with fertile soil and productive agriculture. Anhui is also rich in natural resources, including iron $(\mathrm{Fe})$ in Maanshan, 
coal in Huainan, and copper $(\mathrm{Cu})$ in Tongling, but the related industrial production (e.g. steel industry at Maanshan) has resulted in metal contamination of the soil [1-3].

Recently, contamination of soil by heavy metals has been an increasing environmental issue $[4,5]$. The potentially toxic elements accumulating in soils induce potential contamination of the food chain and endanger ecosystem safety and human health [6-9]. Environmental quality assessment of heavy metal-contaminated soils can disclose the effects of human activities on the soil environment, which also provides theoretical information for the sustainable development of the limited soil resource [10, 11].

Pollution index methods have been widely used to assess soil environment quality, which employ a definite limit to differentiate and quantify the extent of soil pollution $[12,13]$. However, in all environmental quality assessments, owing to inconsistency and peculiarities of each soil pollutant, there is a vagueness or fuzziness in relation to environmental risk [14, 15]. In classification schemes, fuzziness makes it difficult to justify the use of sharp boundaries. This fuzziness has led some environmental researchers to investigate advanced assessment methods based on fuzzy logic [16]. Fuzzy methods comprehensively evaluate the contributions of various pollutants according to predetermined weights, and decrease the fuzziness using membership functions [17]. Fuzzy comprehensive assessment has been proven effective in solving problems of fuzzy boundaries and controlling the effect of monitoring errors on assessment results [18-20].

The objectives of this study were:

1) to comprehensively assess environmental risks of heavy metal pollution in the soils of Anhui Province using pollution index and fuzzy mathematical methods,

2) to compare the assessment results to learn about the application characteristics of the assessment methods.

\section{Materials and Methods}

\section{Soil Sampling and Pretreatment}

A total of 1,361 soil samples were collected from 0 to $20 \mathrm{~cm}$ in depth in the arable farmland in 17 cities of Anhui Province with a total size of about $14 \mathrm{~km}^{2}$ (Fig. 1). In order to assess the temporal variations of metal pollution in the soils, the sampling was separately conducted in 1994 and 2014 with the help of the Environmental Monitoring Central Station of Anhui Province. Since land becomes more uneven in South Anhui, with the Dabie Mountains occupying much of the southwest and a series of hills and

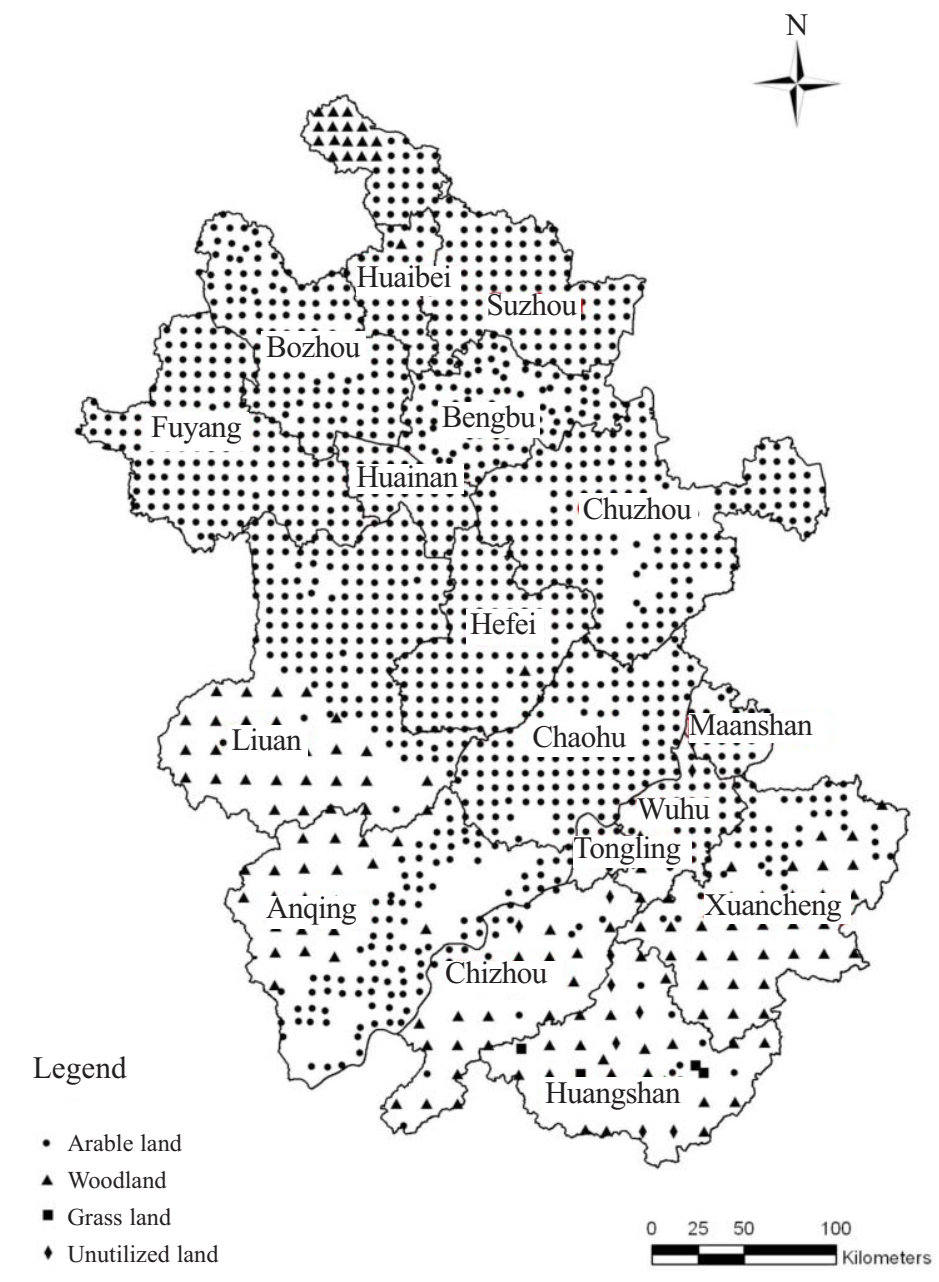

Fig. 1. Location of soil sampling sites in the 17 cities of Anhui Province, China. 
Table 1. Standards used for soil environment quality assessment in this study $(\mathrm{mg} / \mathrm{kg})$.

\begin{tabular}{|c|c|c|c|c|c|}
\hline \multirow{2}{*}{ Metal } & Class I & Class II & Class III & Class IV & Class V \\
\cline { 2 - 6 } & Excellent & Good & Slightly polluted & Moderately polluted & Heavily polluted \\
\hline $\mathrm{As}$ & 20 & 40 & 60 & 100 & 150 \\
\hline $\mathrm{Cd}$ & 0.1 & 0.3 & 0.4 & 0.5 & 1.0 \\
\hline $\mathrm{Co}$ & 15 & 40 & 70 & 120 & 200 \\
\hline $\mathrm{Cr}$ & 78 & 150 & 250 & 100 & 400 \\
\hline $\mathrm{Cu}$ & 20 & 50 & 0.5 & 1.0 & 400 \\
\hline $\mathrm{Hg}$ & 0.1 & 0.3 & 2,400 & 4,000 & 1.5 \\
\hline $\mathrm{Mn}$ & 700 & 1,500 & 60 & 90 & 6,000 \\
\hline $\mathrm{Ni}$ & 30 & 40 & 120 & 300 & 200 \\
\hline $\mathrm{Pb}$ & 35 & 130 & 200 & 300 & 500 \\
\hline $\mathrm{V}$ & 65 & 200 & 300 & 500 & 500 \\
\hline $\mathrm{Zn}$ & 120 & & & 800 \\
\hline
\end{tabular}

ranges cutting through the southeast, few samples were collected in the southern part of the province. Five sub-samples were collected in each sampling point and mixed thoroughly to get a representative sample $(1 \mathrm{~kg})$. The soil samples were dried at $60^{\circ} \mathrm{C}$ in flasks until constant weight was reached, and then screened to pass through a $1 \mathrm{~mm}$ mesh sieve to remove large debris, stones, and pebbles. They were then ground in an agate mortar and screened with a sieve of $0.15 \mathrm{~mm}$ mesh size to get fine particles $(<0.15 \mathrm{~mm})$. The prepared soil samples were sealed in polyethylene bags and stored at $4^{\circ} \mathrm{C}$ for further analyses.

\section{Chemical Analyses}

The samples collected in 1994 and 2014 were treated and analyzed using the same methods for each metal measurement, although the reference literatures were different. For the samples of 2014, air-dried soil samples ( $0.5 \mathrm{~g}$ each) were digested with $\mathrm{HNO}_{3}$ and $\mathrm{H}_{2} \mathrm{O}_{2}$ using method 3050B recommended by United States Environmental Protection Agency (USEPA) [21] prior to analyses of 11 heavy metals. Concentrations of $\mathrm{Cd}, \mathrm{Co}, \mathrm{Cr}, \mathrm{Cu}, \mathrm{Mn}, \mathrm{Ni}, \mathrm{Pb}, \mathrm{V}$, and $\mathrm{Zn}$ were determined using an inductively coupled plasma spectrometer (Jarrell-Ash Mark III 1100). A cold vapor atomic absorption spectrophotometer (Perkin Elmer, Model 5100, PC AAS) was used to measure the $\mathrm{Hg}$ concentration in the soil samples according to the standard method of China's Environmental Protection Agency (GB/T17136-1997), and total As was determined using the spectrophotometric method with potassium borohyride and silver nitrate according to the standard method (China EPA, GB/T171351997). According to the National Environmental Monitoring Centre of China (NEMCC) [22], the 1994 samples were digested and the heavy metals were measured using atomic absorption for $\mathrm{Hg}$, potassium borohyride spectrophotometry for As, and inductively coupled plasma spectrometry for other metals, which were the same with those for the samples collected in 2014. The detection limits of the methods used in this study were $0.01 \mathrm{mg} / \mathrm{kg}$ (AS), $0.01 \mathrm{mg} / \mathrm{kg}(\mathrm{Cd}), 0.02 \mathrm{mg} / \mathrm{kg}(\mathrm{Co}), 0.03 \mathrm{mg} / \mathrm{kg}(\mathrm{Cr}), 0.02$ $\mathrm{mg} / \mathrm{kg}(\mathrm{Cu}), 0.005 \mathrm{mg} / \mathrm{kg}(\mathrm{Hg}), 0.02 \mathrm{mg} / \mathrm{kg}(\mathrm{Mn}), 0.02$ $\mathrm{mg} / \mathrm{kg}(\mathrm{Ni}), 0.01 \mathrm{mg} / \mathrm{kg}(\mathrm{Pb}), 0.03 \mathrm{mg} / \mathrm{kg}(\mathrm{Zn})$, and 0.02 $\mathrm{mg} / \mathrm{kg}(\mathrm{V})$.

\section{Pollution Index Assessment Methods}

The 11 heavy metals were selected as pollution indices to assess the soil environment quality of Anhui Province. Assessment criteria were established based on the actual local situation and the National Environmental Quality Standards of China. Accordingly, soil quality was classified into five levels: Class I, excellent; Class II, clean; Class III, slightly polluted; Class IV, moderately polluted; and Class V, heavily polluted (Table 1).

Two pollution index methods (single-factor index and Nemero comprehensive index) were used to evaluate soil quality. The single-factor index method can be expressed as:

$$
P_{i}=C_{i} / S_{i}
$$

... and the calculation formula of the Nemero comprehensive index method is:

$$
P=\sqrt{\frac{\left(\frac{1}{n} \sum_{i=1}^{n} P_{i}\right)^{2}+\left[\max \left(P_{i}\right)\right]^{2}}{2}}
$$

...where $P_{i}$ is the pollution index of pollutant $i ; C_{i}(\mathrm{mg} / \mathrm{kg})$ is the actual monitoring data of soil pollutant $i ; S_{i}(\mathrm{mg} / \mathrm{kg})$ 
Table 2. Weight of metal indices in fuzzy mathematics models used for environmental quality assessment on the soils of different cities.

\begin{tabular}{|c|c|c|c|c|c|c|c|c|c|c|c|}
\hline City Metal & As & $\mathrm{Cd}$ & Co & $\mathrm{Cr}$ & $\mathrm{Cu}$ & $\mathrm{Hg}$ & $\mathrm{Mn}$ & $\mathrm{Ni}$ & $\mathrm{Pb}$ & V & $\mathrm{Zn}$ \\
\hline Anqing & 0.05 & 0.12 & 0.07 & 0.11 & 0.08 & 0.03 & 0.09 & 0.12 & 0.06 & 0.17 & 0.09 \\
\hline Bengbu & 0.06 & 0.12 & 0.07 & 0.13 & 0.08 & 0.02 & 0.10 & 0.13 & 0.06 & 0.16 & 0.07 \\
\hline Bozhou & 0.06 & 0.12 & 0.06 & 0.12 & 0.08 & 0.02 & 0.09 & 0.15 & 0.06 & 0.16 & 0.08 \\
\hline Chaohu & 0.06 & 0.10 & 0.07 & 0.13 & 0.08 & 0.03 & 0.09 & 0.14 & 0.06 & 0.18 & 0.07 \\
\hline Chizhou & 0.06 & 0.15 & 0.06 & 0.10 & 0.07 & 0.04 & 0.09 & 0.12 & 0.07 & 0.16 & 0.09 \\
\hline Chuzhou & 0.05 & 0.09 & 0.07 & 0.14 & 0.07 & 0.02 & 0.09 & 0.16 & 0.06 & 0.16 & 0.07 \\
\hline Fuyang & 0.06 & 0.13 & 0.06 & 0.12 & 0.08 & 0.02 & 0.09 & 0.15 & 0.06 & 0.16 & 0.08 \\
\hline Hefei & 0.06 & 0.07 & 0.07 & 0.14 & 0.08 & 0.02 & 0.08 & 0.14 & 0.06 & 0.17 & 0.11 \\
\hline Huaibei & 0.06 & 0.11 & 0.06 & 0.13 & 0.08 & 0.02 & 0.08 & 0.16 & 0.06 & 0.16 & 0.08 \\
\hline Huainan & 0.07 & 0.08 & 0.07 & 0.13 & 0.08 & 0.02 & 0.09 & 0.16 & 0.06 & 0.17 & 0.08 \\
\hline Huangshan & 0.06 & 0.13 & 0.06 & 0.09 & 0.08 & 0.05 & 0.09 & 0.10 & 0.06 & 0.17 & 0.11 \\
\hline Liuan & 0.04 & 0.11 & 0.07 & 0.13 & 0.07 & 0.03 & 0.09 & 0.14 & 0.06 & 0.18 & 0.08 \\
\hline Maanshan & 0.05 & 0.15 & 0.06 & 0.11 & 0.08 & 0.06 & 0.08 & 0.13 & 0.05 & 0.15 & 0.08 \\
\hline Suzhou & 0.06 & 0.12 & 0.05 & 0.12 & 0.08 & 0.02 & 0.09 & 0.15 & 0.06 & 0.15 & 0.09 \\
\hline Tongling & 0.05 & 0.17 & 0.04 & 0.12 & 0.08 & 0.03 & 0.08 & 0.11 & 0.07 & 0.14 & 0.09 \\
\hline Wuhu & 0.06 & 0.16 & 0.06 & 0.12 & 0.09 & 0.02 & 0.06 & 0.14 & 0.06 & 0.16 & 0.09 \\
\hline Xuancheng & 0.06 & 0.09 & 0.07 & 0.11 & 0.07 & 0.04 & 0.09 & 0.13 & 0.06 & 0.19 & 0.09 \\
\hline
\end{tabular}

is the environmental background value of pollutant $i$ in Anhui Province; and $P$ is the Nemero comprehensive pollution index.

\section{Fuzzy Mathematics Assessment Methods}

Membership functions represent the degrees to which the specified concentration belongs to the fuzzy set. The membership degrees of pollutants at each level can be determined by a set of formulas of membership functions as follows:

$$
u_{i, m}= \begin{cases}1-u_{m-1}\left(C_{i}\right) & e_{m-1} \leq C_{i} \leq e_{m} \\ \left(e_{m+1}-C_{i}\right) /\left(e_{m+1}-e_{m}\right) & e_{m} \leq C_{i} \leq e_{m+1} \\ 0 & C_{i} \geq e_{m+1}\end{cases}
$$

...where $u_{i, m}$ is the membership degree of pollution index $i$ at class $m, C_{i}(\mathrm{mg} / \mathrm{kg})$ is the actual monitoring data of pollution index $i$, and $e_{m}(\mathrm{mg} / \mathrm{kg})$ is the criteria value at class $m$.

After substituting the monitoring data of each pollution index at each sampling site and the assessment criteria into the membership function, one fuzzy matrix was obtained for each sampling location. For example, the fuzzy matrix of Tongling City in 2014 was expressed as:

$$
\mathrm{R}_{\mathrm{A}}=\left|\begin{array}{ccccc}
1.00 & 0 & 0 & 0 & 0 \\
0 & 0 & 1.00 & 0 & 0 \\
1.00 & 0 & 0 & 0 & 0 \\
1.00 & 0 & 0 & 0 & 0 \\
0.32 & 0.68 & 0 & 0 & 0 \\
1.00 & 0 & 0 & 0 & 0 \\
1.00 & 0 & 0 & 0 & 0 \\
1.00 & 0 & 0 & 0 & 0 \\
1.00 & 0 & 0 & 0 & 0 \\
0.42 & 0.58 & 0 & 0 & 0 \\
1.00 & 1.00 & 1.00 & 0 & 0
\end{array}\right|
$$

It is very important to choose the appropriate weight for each factor since the contribution to integrated environmental quality varies greatly among the different water quality parameters. The weight of each pollution index at certain monitoring locations was allocated according to: 


$$
W_{i, k}=\frac{C_{i, k} / A_{i}}{\sum_{i=1}^{n} C_{i, k} / A_{i}}
$$

...where $W_{i, k}$ is the weight of pollution index $i$ at location $k$, $C_{i, k}(\mathrm{mg} / \mathrm{kg})$ is the detection results of pollution index $i$ at location $k$, and $A_{i}(\mathrm{mg} / \mathrm{kg})$ is the average assessment criteria of pollution index $i$.

In this study, the weights were selected based on both soil quality assessment criteria and the actual detection data. Here, $C_{i, k}$ indicated the extent of exceeding the average assessment criterion since it was assumed that this included the difference among the pollutant elements and the pollution degree.

According to Equation (4), the weights of the 11 pollution indices were obtained for the soil sampling locations of 17 cities (Table 2). The soil environment quality of the 17 cities were assessed using two fuzzy mathematical methods: single-factor deciding and weighted-average model. Calculation of the single-factor deciding model was performed according to:

$$
b_{m}=\operatorname{Max}_{i=1}^{n} W_{i} u_{i, m}
$$

...and the weighted-average model can then be expressed as:

$$
b_{m}=\sum_{i=1}^{n} W_{i} u_{i, m}
$$

...where $b_{m}$ is the membership degree of final assessment result at class $m, W_{i}$ is the weight of pollution index $i$ at the sampling location, and $u_{i, m}$ is the membership degree of pollution index $i$ at class $m$.

The assessment vectors of the single-factor deciding model were normalized before application of the results to assess the soil environment quality.

\section{Statistical Analyses}

Experimental results were statistically analyzed using SPSS 11.0 (SPSS Inc., Chicago, USA). All values were expressed as mean \pm standard deviation (SD). The significance of the difference in the metal concentrations among different sampling times or sites was assessed with Independent Samples t-Test. A $p<0.05$ was considered statistically significant.

\section{Results and Discussion}

\section{Concentration of Metals in the Anhui Soils}

Figs. 2 and 3 show the average concentration of the 11 metals in the soils of the 17 cities of Anhui Province in 1994 and 2014. For the whole province, the mean of the
Table 3. Assessment on soil environment quality using pollution index methods.

\begin{tabular}{|l|c|c|c|c|}
\hline $\begin{array}{c}\text { Assessment } \\
\text { model }\end{array}$ & \multicolumn{2}{c|}{$\begin{array}{c}\text { Single-factor } \\
\text { index }\end{array}$} & \multicolumn{2}{c|}{$\begin{array}{c}\text { Comprehensive } \\
\text { index }\end{array}$} \\
\hline City & 1994 & 2014 & 1994 & 2014 \\
\hline Anqing & I & I & I & I \\
\hline Bengbu & I & II & I & I \\
\hline Bozhou & I & II & I & I \\
\hline Chaohu & I & I & I & I \\
\hline Chizhou & I & II & I & II \\
\hline Chuzhou & II & I & I & I \\
\hline Fuyang & I & II & I & I \\
\hline Hefei & I & I & I & I \\
\hline Huaibei & II & II & I & I \\
\hline Huainan & I & II & I & I \\
\hline Huangshan & I & II & I & I \\
\hline Liuan & II & I & I & I \\
\hline Maanshan & I & II & I & I \\
\hline Suzhou & I & II & I & I \\
\hline Tongling & I & III & I & III \\
\hline Wuhu & II & II & I & I \\
\hline Xuancheng & & I & I \\
\hline
\end{tabular}

metal concentrations in 2014 followed this order: $\mathrm{Mn}>\mathrm{V}$ $>\mathrm{Zn} / \mathrm{Cr}>\mathrm{Pb} / \mathrm{Ni} / \mathrm{Cu}>\mathrm{Co}>\mathrm{As}>\mathrm{Cd}>\mathrm{Hg}$. In 1994 it was also found that the average concentration was highest for $\mathrm{Mn}(479.8 \mathrm{mg} / \mathrm{kg})$ and lowest for $\mathrm{Hg}(0.037 \mathrm{mg} / \mathrm{kg})$. In the past 20 years, soil $\mathrm{Cd}, \mathrm{Co}, \mathrm{Mn}$, and $\mathrm{Cu}$ concentrations demonstrated an increasing trend in Anhui Province. For example, Cd concentration increased from $0.089 \mathrm{mg} / \mathrm{kg}$ in 1994 and $0.162 \mathrm{mg} / \mathrm{kg}$ in 2014 ( $\mathrm{p}<0.05$ ). However, the concentrations of other metals showed no evident changes in the same timespan.

Among the different cities, Tongling and Chizhou were most seriously polluted by heavy metals in soil in 1994 since the total concentration of 11 metals was highest in the two cities. In 1994, only Tongling City had total metal concentrations over $1,000 \mathrm{mg} / \mathrm{kg}$, but in 2014 the seriously polluted cities included Bengbu, Chizhou, Fuyang, Huannai, Huangshan, and Maanshan. In 1994, Cr, Mn, and $\mathrm{Pb}$ each had higher concentrations in Tongling than in other cities, but in 2014 Tongling soils were mainly contaminated by $\mathrm{Cd}, \mathrm{Hg}, \mathrm{Cu}$, and $\mathrm{Zn}$. In 2014, among the cities Fuyang had the highest Mn concentration, and Tongling and Chizhou had much higher $\mathrm{Cd}$ concentrations than other cities. Compared with other cities, Maanshan had the most concentration of $\mathrm{Hg}$ in soils during the past 20 years. 
Comparison between Two Pollution Index Methods

Table 3 shows that the soil environment quality of most cities in 1994 was determined to be Class I by using the single-factor pollution index method according to the principle of maximum membership grade, and the other was assigned to Class II. However, in 2014 the quality was seriously deteriorated since most of cities (10/17) had the soil environment quality of Class II. However, through the comprehensive index method, soil environment quality of each city in 1994 was identified as Class I. It should be noted that the two assessment methods consistently revealed the soil quality of Class I in 1994, but Class III in 2014 in Tongling City. Tongling's industrial base has been revolving around the several nearby copper mines and copper processing operations for years. The local mineral resources also include iron, coal, gold, silver, tin, and iron sulfide, plus more than 20 rare minerals such as nickel, cadmium, gallium, molybdenum, germanium, and selenium (http://www.tl.gov.cn/).
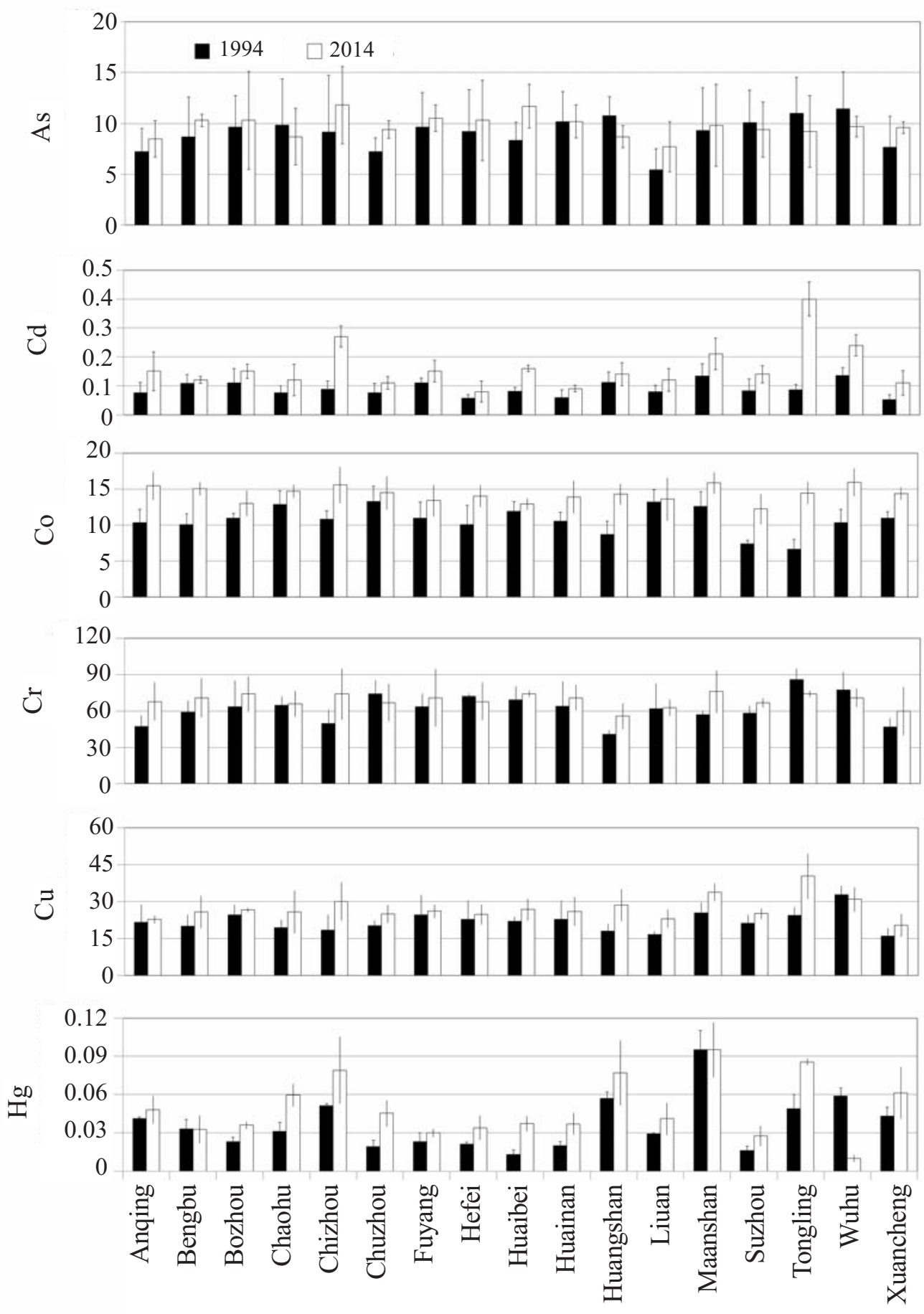

Fig. 2. Concentrations (mg/kg) of As, Cd, Co, Cr, Cu, and $\mathrm{Hg}$ in the farmland soil of the 17 cities of Anhui Province detected in 1994 and 2014. 
The mineral-dependent industrial development may contribute to the deterioration of soil quality in this city.

Comparison between two pollution index methods demonstrated that the assessment results of single-factor index were worse than those of the comprehensive index for the environmental quality of the assessed soils. The distinction of the assessment principle between the two methods resulted into the different assessment results. Only the maximum contributing factors were introduced into the single- factor index method, and other factors were neglected in the method. Thereby, in practical assessment work, it is usually found that the factors with high concentration (heavily polluted) have a fateful influence on the final assessment results of the single-factor method [23]. However, the dominant parameter and average contribution of all factors were both taken into account for the comprehensive index method used in this study, which resulted in better environmental quality for the comprehensive index method [13].
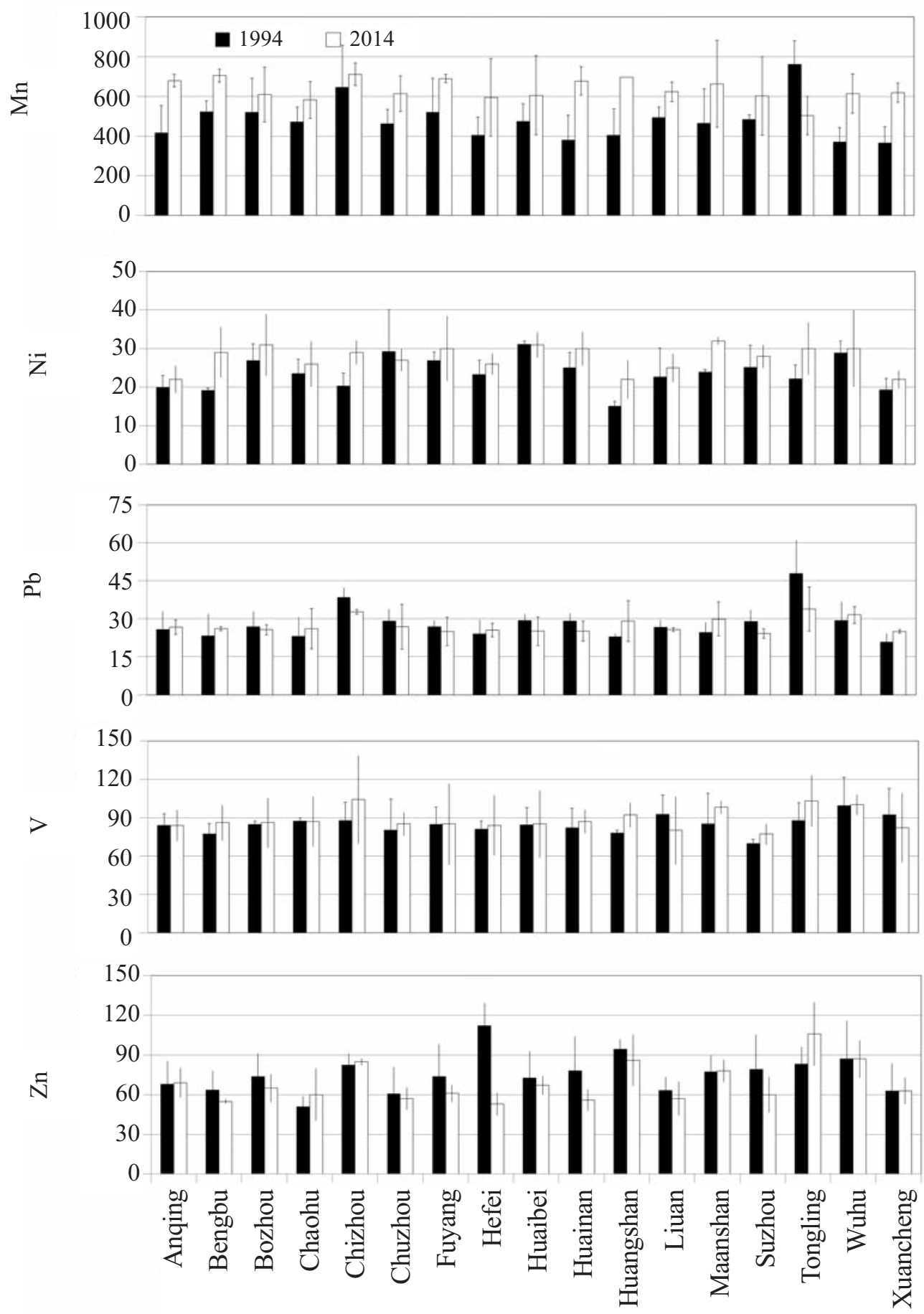

Fig. 3. Concentrations ( $\mathrm{mg} / \mathrm{kg}$ ) of $\mathrm{Mn}, \mathrm{Ni}, \mathrm{Pb}, \mathrm{V}$, and $\mathrm{Zn}$ in the farmland soil of the 17 cities of Anhui Province detected in 1994 and 2014. 


\section{Comparison between the Two Fuzzy} Mathematical Methods

Table 4 shows that the two fuzzy mathematical methods shared a common assessment result for soil heavy metals pollution in 1994, and the soil environment quality of each city was determined to be Class I. However, with the single-factor decision model, the soil quality in 2014 was determined to be Class II for Bozhou, Chizhou, and Wuhu, and Class III for Tongling. Weighted-average assessment showed that Tongling soil quality showed Class II and other cities showed Class I in 2014. Assessment with the two models showed that the soil quality of Anhui tended to be worse during the past 20 years, which is consistent with the results from pollution index methods.

Although the two fuzzy mathematical methods often shared common results in the soil quality of some cities, differences in membership degree to each pollution class still existed between the two methods (Fig. 4). In each assessed city, as far as the sum of membership degree to Class I was concerned, the value of single-factor deciding model was lower than that of weighted average model. However, in terms of the sum of membership degree to classes II, III, IV, and V, the value of the single-factor deciding model was higher than that of weighted average model. For example, calculated with a single-factor deciding model, the membership degree to Class I was 0.24 in Tongling (2014), and the sum of the membership degree to classes II, III, IV, and V was 0.76 . While calculated with weighted average model, the two values were $0.60(>0.24)$ and $0.40(<0.76)$, respectively. Therefore, the single-factor
Table 4. Assessment on soil environment quality using fuzzy mathematical methods.

\begin{tabular}{|c|c|c|c|c|}
\hline \multirow{2}{*}{$\begin{array}{c}\begin{array}{c}\text { Assessment } \\
\text { model }\end{array} \\
\text { Sampling }\end{array}$} & \multicolumn{2}{|c|}{ Single-factor decision } & \multicolumn{2}{|c|}{ Weighted-average } \\
\hline & 1994 & 2014 & 1994 & 2014 \\
\hline Anqing & I & I & I & I \\
\hline Bengbu & I & I & I & I \\
\hline Bozhou & I & II & I & I \\
\hline Chaohu & I & I & I & I \\
\hline Chizhou & I & II & I & I \\
\hline Chuzhou & I & I & I & I \\
\hline Fuyang & I & I & I & I \\
\hline Hefei & I & I & I & I \\
\hline Huaibei & I & I & I & I \\
\hline Huainan & I & I & I & I \\
\hline Huangshan & I & I & I & $\mathrm{I}$ \\
\hline Liuan & I & I & I & I \\
\hline Maanshan & I & I & I & I \\
\hline Suzhou & I & I & I & I \\
\hline Tongling & I & III & I & II \\
\hline Wuhu & I & II & I & I \\
\hline Xuancheng & I & I & I & I \\
\hline
\end{tabular}

A)

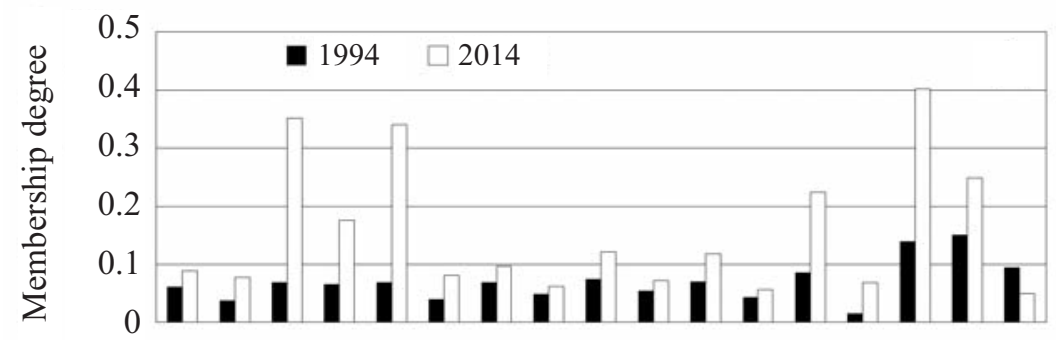

B)

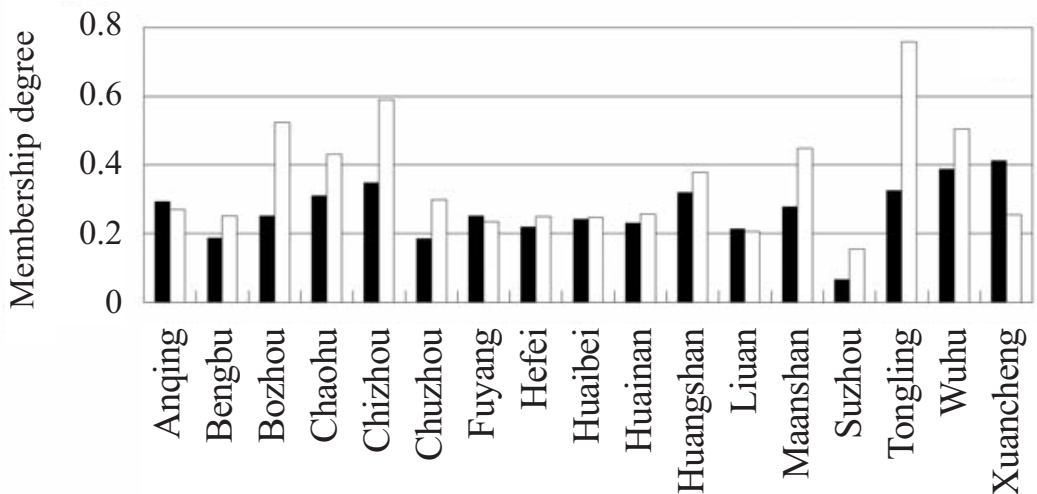

Fig. 4. Membership degrees for classes II, III, IV, and V of soils calculated using the single-factor (A) and weighted-average (B) models. 
deciding model provides the assessment results of heavier contamination than weighted average model.

Like the relationship between the two pollution index methods, the assessment results of weighted average model were slightly better than those of the single-factor deciding model. The difference of the assessment results was attributed to the distinct assessment objectives and principle $[15,24]$. In the single-factor deciding model, the most dominant factor received more attention, and the effects of the other factors are weakened. However, in weighted average model, the contribution of each factor was well taken into account, and the weights were allocated for the factors according their contribution degree, so the assessment results of the weighted average model depended on the integrated effects of all factors to a great extent [25].

\section{Comparison between Pollution Index Methods and Fuzzy Mathematical Methods}

Tables 3 and 4 show that the assessment results of environmental quality will tend to be better if using fuzzy mathematical methods, but they will become worse if using pollution index methods. In pollution index methods, a simple number was marked as a limit to divide two distinct grades of pollution degree. For example, in Fuyang (2014), V concentration was $85 \mathrm{mg} / \mathrm{kg}$, and the two closest environmental criteria values were 65 (Class I) and $130 \mathrm{mg} / \mathrm{kg}$ (Class II). It is self-evident that the number 85 is closer to the number 65 than to 130 , but using the pollution index method, the soil quality of Fuyang was determined to be Class II in terms of V pollution. In fuzzy methods, fuzziness logic makes the use of criteria's sharp boundaries hard to justify. Membership functions were used to describe the limit between different pollution degrees. The membership degrees of 85 to 65 and to 130 were 0.69 and 0.31 , respectively, which demonstrated that Class I - not Class II - was more reasonable to be assigned to the level of environmental risk caused by heavy metal $\mathrm{V}$ pollution in Fuyang.

At the same time, different from pollution index methods, fuzzy mathematical methods were established with more attention to the contribution of all factors to the integrated pollution [26]. Different weights were allocated for different factors, and the weight reflected the contributing capacity of each factor [16]. For example, in Tongling City, contribution degrees of the pollutants are listed as follows: $\mathrm{Cd}>\mathrm{V}>\mathrm{Cr}>\mathrm{Ni}>\mathrm{Zn}>\mathrm{Cu}>\mathrm{Mn}>\mathrm{Pb}>\mathrm{As}>\mathrm{Co}>\mathrm{Hg}$ (Table 2). The introduction of weight to environmental assessment made fuzzy mathematical methods more reasonable than pollution index methods [13].

The single-factor methods (including single-factor index method and single-factor deciding model) are applicable in the situation where the individual evaluation factor is over proof and the assessment aim is to externalize the principle of single factor rejection, while the comprehensive methods (including the Nemero pollution index method and the weighted average model) are applicable in the situation that the contents of evaluation factors are even and the evaluation aim is to externalize the role of each assessment index in soil environment quality [16].
Therefore, in practical work, it is necessary to select a suitable model according to monitoring data and assessment objectives in order to make the assessment results satisfactory for practical requirements and close to the facts.

\section{Conclusions}

1. The concentrations of 11 metals in the soils sampled in 1994 and 2014 from the 17 cities of Anhui Province were determined in this study. Generally, Mn always had the highest concentration and $\mathrm{Hg}$ had the lowest concentration among the metals. In the past 20 years, soil $\mathrm{Cd}, \mathrm{Co}, \mathrm{Mn}$, and $\mathrm{Cu}$ concentrations demonstrated an increasing trend in the province. In 1994, only Tongling City had total metal concentration over 1,000 $\mathrm{mg} / \mathrm{kg}$, but in 2014 the seriously polluted cities included Bengbu, Chizhou, Fuyang, Huannai, Huangshan, and Maanshan.

2. Two pollution index methods and two fuzzy mathematical methods were employed to investigate the soil environment quality of 17 cities of Anhui. The assessment result of the single-factor index method was of Class I or Class II for each soil, while the results of the comprehensive index method were of Class I in more cases, which were better than those of the single-factor method. In comparison with the single-factor index method, the comprehensive index method concerned both dominant parameters and average contribution of all factors to integrated environmental quality.

3 . Using the two fuzzy mathematical methods (singlefactor deciding model and weighed average model), the soil environment quality of each city was identified to be Class I, but a difference of the membership degree to each pollution class still existed between the two methods. The assessment results of the weighted average model were slightly better than those of the singlefactor deciding model in this study. The difference may result from the different assessment objectives and principles of the two fuzzy methods.

4. In the pollution index method, environmental quality was divided into several grades with sharp boundaries, while in the fuzzy mathematical method, fuzziness made the use of criteria's sharp boundaries hard to justify. Membership functions were used to describe the limit between different pollution degrees, and different weights were allocated for the factors according to their pollution contribution in the fuzzy mathematical methods. Introduction of membership degree and weight of each factor to the fuzzy methods made them more reasonable in the field of environmental assessment.

\section{Acknowledgements}

This study was financially supported by the Social Science Foundation of Jiangsu, China (11SHC010), and the Technological Support Foundation of Lianyungang, China (SH1202). 


\section{References}

1. LI H.X., XU Q.J., ZHANG D.Q. Heavy metal pollution of soil around the Gangue Hill: A case study from Zhuxiangzhuang Coal Mine, Northern Anhui Province, China. Adv. Mater. Res. 356, 114, 2011.

2. QI C.C., LIU G.J., KANG Y., LAM P.K.S., CHOU C.L. Assessment and distribution of antimony in soils around three coal mines, Anhui, China. JAPCA J. Air Waste Ma. 61, (8), 850, 2011.

3. SUN L., GUI H.R., XU D.S., HUANG S.L. Heavy metal pollution in rural area of China: A case study of pond sediments from Sixian Country, Northern Anhui Province. Fresen. Environ. Bull. 21, (2), 263, 2012.

4. LIN Y., WENG C., LEE S. Spatial distribution of heavy metals in contaminated agricultural soils exemplified by $\mathrm{Cr}$, $\mathrm{Cu}$, and Zn. J. Environ. Eng.-ASCE 138, 299, 2012.

5. LIN W., XIAO T., ZHOU W., NING Z. Pb, Zn, and Cd distribution and migration at a historical zinc smelting site. Pol. J. Environ. Stud. 24, (2), 575, 2015.

6. REYNDER H., BERVOETS L., GELDERS M., DE COEN W.M., BLUST R. Accumulation and effects of metals in caged carp and resident roach along a metal pollution gradient. Sci. Total Environ. 391, (1), 82, 2008.

7. ABDELHAFEZ A.A., LI J. Environmental monitoring of heavy metal status and human health risk assessment in the agricultural soils of the Jinxi River Area, China. Human Ecol. Risk Assess. 21, (4), 952, 2015.

8. ABDELHAFEZ A.A., ABBAS M.H.H., ATTIA T.M.S. Environmental monitoring of heavy-metals status and human health risk assessment in the soil of Sahi El-Hessania Area, Egypt. Pol. J. Environ. Stud. 24, (2), 459, 2015.

9. VITTORI ANTISARI L., CARBONE S., GATTI A., VIANELLO G., NANNIPIERI P. Uptake and translocation of metals and nutrients in tomato grown in soil polluted with metal oxide $\left(\mathrm{CeO}_{2}, \mathrm{Fe}_{3} \mathrm{O}_{4}, \mathrm{SnO}_{2}, \mathrm{TiO}_{2}\right)$ or metallic (Ag, Co, $\mathrm{Ni}$ ) engineered nanoparticles. Environ Sci Pollut Res Int. 22, (3), 1841, 2015.

10. OBERG T., BERBACK B. A review of probabilistic risk assessment of contaminated land. J. Soils Sediments 5, (4), 213, 2005.

11. LIU J., ZHOU Z., SUN S., NING X., ZHAO S., XIE W., WANG Y., ZHENG L., HUANG R., LI B. Concentrations of heavy metals in six municipal sludges from Guangzhou and their potential ecological risk assessment for agricultural land use. Pol. J. Environ. Stud. 24, (1), 165, 2015.

12. 12 HE T., LIAO B.H., ZENG M., LEI M., ZENG Q.R., ZHANG Y., GUO H. Investigation on arsenic pollution of paddy fields in 4 mining areas in southern Hunan. Asian J. Ecotoxicol. 2, 470, 2007.
13. TUTMEZ B., KAYMAK U., TERCAN A.E. Local spatial regression models: a comparative analysis on soil contamination. Stoch. Env. Res. Risk A. 26, (7), 1013, 2012.

14. LIU J., LI Y. P., HUANG G.H. Mathematical modeling for water quality management under interval and fuzzy uncertainties. J. Appl. Math. 21, 1, 2013.

15. MCKONE T.E., DESHPANDE A.W. Can fuzzy logic bring complex environmental problems into focus? Environ. Sci. Technol. 39, 42A, 2005.

16. FISHER B. Fuzzy environmental decision-making: Applications to air pollution. Atmos. Environ. 37, 1865, 2003.

17. LIU J., LI Y.P., HUANG G.H., NIE S. Development of a fuzzy-boundary interval programming method for water quality management under uncertainty. Water Resour. Manag. 29, (4), 1169, 2015.

18. SADIQ R., HUSAIN T. A fuzzy-based methodology for an aggregative environmental risk assessment: A case study of drilling waste. Environ. Modell. Softw. 20, 33, 2005.

19. SHEN G.Q., LU Y.T., WANG M.N., SUN Y.Q. Status and fuzzy comprehensive assessment of combined heavy metal and organo-chlorine pesticide pollution in the Taihu Lake region of China. J. Environ. Manage. 76, 355, 2005.

20. WANG H.Y. Assessment and prediction of overall environmental quality of Zhuzhou City, Hunan Province, China. J. Environ. Manage. 66, 329, 2002.

21. USEPA (United States Environmental Protection Agency). Acid Digestion of Sediments, Sludges and Soils. Method 3050B. USEPA, Washington D.C., 1996.

22. NEMCC (National Environmental Monitoring Centre of China). Modern Analytical Methods of Soil Elements. China Environmental Science Press, Beijing, 1992.

23. CHEN T.B., ZHENG Y.M., LEI M., HUANG Z.C., WU H.T., CHEN H., FAN K.K., YU K., WU X., TIAN Q.Z. Assessment of heavy metal pollution in surface soils of urban parks in Beijing, China. Chemosphere 60, 542, 2005.

24. LUO W., LU Y.L., GIESY J.P., WANG T.Y., SHI Y.J., WANG G., XING Y. Effects of land use on concentrations of metals in surface soils and ecological risk around Guanting Reservoir, China. Environ. Geochem. Hlth. 29, 459, 2007.

25. GELDERMANN J., SPENGLER T., RENTZ O. Fuzzy outranking for environmental assessment. Case study: Iron and steel making industry. Fuzzy Set. Syst. 115, 45, 2000.

26. SZCZEPANIAK K., SÂRBU C., ASREL A., RAIŃSKA E., BIZIUK M., CULICOV O., FRONTASEVA M.V., BODE P. Assessment of the impact of a phosphatic fertilizer plant on the adjacent environment using fuzzy logic. Cent. Eur. J. Chem. 4, 29, 2006. 